\section{SOI: 1.1 TAS DOI: 10.15863 /TAS International Scientific Journal Theoretical \& Applied Science}

\author{
p-ISSN: 2308-4944 (print) e-ISSN: 2409-0085 (online)
}

Year: 2017 Issue: $01 \quad$ Volume: 45

Published: $30.01 .2017 \quad$ http://T-Science.org
Shavkat Nishonovich Turaev

$\mathrm{PhD}$, Deputy of the Head of Scientific and practical Centre for National idea and ideology

Tashkent, Uzbekistan

\title{
SOME ASPECTS OF PERFECTION OF MECHANISMS OF SPIRITUAL THREATS PREVENTING
}

\begin{abstract}
Language: English
\section{Introduction}

By the end of the twentieth century, especially actualized issues related to the spiritual renewal of society and the problems associated with the formation of a new paradigm of thinking and spiritual activity. The collapse of the bipolar ideological reality has led to a certain ideological vacuum, which is characteristic of almost all postSoviet space. The need to choose your own path of development before the new young sovereign states of a number of problems has delivered not only in the political, social and economic fields, but also in the spiritual.
\end{abstract}

Abstract: The development of the modern world involves not only the positive aspects of globalization processes, the mass of information, increasing of information flows, but also the ability to confront the threats that can bring significant harm to the consciousness of people, especially young people. First of all we are talking about the spiritual dangers faced by our country during the years of independence. The article discusses some aspects of the improvement of methods, techniques and methodology of confrontation of different kind of spiritual threats.

Key words: progress, regress, globalization, national idea, spirituality, spiritual threats, "mass culture", perfection, education, national and universal values, traditions and customs, religious values.

Citation: Turaev SN (2017) SOME ASPECTS OF PERFECTION OF MECHANISMS OF SPIRITUAL THREATS PREVENTING. ISJ Theoretical \& Applied Science, 01 (45): 86-88.

Soi: http://s-o-i.org/1.1/TAS-01-45-17 Doi: crossef https://dx.doi.org/10.15863/TAS.2017.01.45.17

\section{Materials and Methods}

Spirituality is the concept is complex and multifaceted. There are many definitions of this term. It is possible to identify some of them [3].

Spirituality is a set of philosophical, legal, scientific, artistic, moral, religious ideas and concepts that reflect the inner world of man, society and the nation.

Spirituality is a state of mind, consciousness, taste, vision, human intelligence, his ability to distinguish between justice and baseness, good and evil, beauty and ugliness, viciousness and selfrestraint, the ability to nominate high goals and ideas, his internal potential and the desire to implement it.
Spirituality is a combination of sincere and intelligent people in the world. Spirituality is the basis of the culture of the individual and society is an important factor in determining the direction of their lives. It has a strong influence on the formation of social and economic life, its reform, progress or regress. If spirituality of population is enriched the country is prosperous, and conversely, if spirituality is impoverished, the people will lose their strength, energy, degrades.

Characterized by different aspects and moments of spiritual crisis has affected all sectors of society, all the structural components of modern civilization. It is not so much to strengthen the impact of various types of aggressive ideas and ideologies, as well as the inability to resist the many members of the community spiritual challenges of our time.

To overcome the crisis it is necessary spiritual revival of spiritual culture in its secular and religious forms, the development of science and education, ethical education, the formation of a new world spirituality. All these factors are related to the improvement of education and training systems, launching into a new level of ideological education, promote the spirit and values of the true human and national values, transmission and interpretation of religious knowledge, the formation of the religious consciousness of people who want to get acquainted with the religion, their values and basic settings . 
The large gap in awareness of religious values, the formation of religious world outlook, fell on the years of the Soviet regime, when the basic idea was to the marxism-leninism, and religious setting focused on atheism. In this connection, in the territory of the Central Asian republics have sprouted movements and organizations, fed from the outside, in order to promote their interests, and that the most dangerous, under the guise of religious values. This type of spiritual threats took place in Uzbekistan. Emissaries of the organizations and movements of extremist and terrorist wing deployed its activity in our country and, under the cover of the banner of Islam, carried out its activity with a view to the enslavement of consciousness mainly young people, to use it as a weapon to achieve their selfish goals.

In order to prevent any kind of negative effects of spiritual threats in Uzbekistan a number of measures for the ideological struggle with them has adopted. Thus, for example, it has developed a national idea and ideology, which was designed to solve the problem of ideological vacuum with the introduction of ideological immunity. Even at the dawn of our independence, the 1st President of the Republic of Uzbekistan Islam Karimov expressed the idea that the "ideological polygons become more dangerous than nuclear" [2]. Indeed, referring to the realities of the present day, we can say that all the armed conflicts taking place on the planet are caused by ideological and religious misunderstanding, unconscious motives, driving man to destruction and murder. The main objective of the national ideology is the fight against manifestations of spiritual threats.

Among the methods of struggle with spiritual threats in particular are the following [2]:

1. The sole purpose of national spirituality and education is the education of the population, the development of its religious beliefs, enriching the inner senses, learning to use in the life of the acquired knowledge.

2. Formation of people relevant qualities, formation and development of their positive social qualities.

3. The introduction into the consciousness of the younger generation a sense of loyalty and devotion to the Motherland, good conduct and morality, diligence, hospitality, faith and beliefs.

4. In the education we must follow from simple to complex, from the known to the unknown, from general to specific, with the help of clarity and consistency to present students with the knowledge in an accessible language for them, to life examples and modern teaching methods.

5. Effective use of such means of spiritual education, as an example, a model, will, love, respect and compassion.

The main task of education today is to educate youth in the spirit of patriotism and devotion to the national idea, forming in their hearts national pride, education of young generation in the spirit of respect for national spiritual and historical values, as well as experts in our rich heritage and modern knowledge.

An important pillar of the country's future in opposition to the various spiritual threats, penetrating into the country under the guise of "mass culture", strengthening the ideological immunity, the organization of substantial leisure of youth, the promotion of national spirit and cultural heritage is to visit places of worship, evidence of our rich history, bringing to theaters as spiritual food, the implementation of work on the festivals, competitions, intellectual games.

It should be noted that due to the independence of the country has created all necessary conditions for the formation of the younger generation of career counseling. This becomes important in the education of young people useful to society personalities, have a deep thinking and high talent. However, in this respect, still have a lot of work. The President of Uzbekistan Shavkat Mirziyoyev suggested that it is necessary to strengthen control over the reform of the education system as a whole, training and retraining of really highly qualified personnel [8].

Among the dangerous spiritual threats in addition to the above concern also penetrating under the guise of "mass culture" moral turpitude, and violence, the spread of ideas of individualism, selfcenteredness, the dangerous threats directed at the disrespect and the destruction of thousands of years of traditions and values, spiritual roots of the prevailing lifestyle and others.

\section{Conclusion}

For the purpose of the spiritual and ideological prevention must first instill in children a sense of patriotism against the threat of "mass culture", keep families educate about national history, values and traditions, to carry out various promotional activity, meetings and open talks.

The events of spiritual, educational and cultural nature play an important role in educating of younger generation in the spirit of loyalty to the motherland and the ideas of independence. Also a big role in confronting the spiritual threats are the media, in particular periodicals and their electronic copies on the Internet, the pages are published analytical and journalistic articles on the protection of consciousness on people, especially young people from all sorts of ideological and information threats in modern conditions.

All these methodological approaches are designed to expose the goal of spiritual, ideological, information and other threats, to educate youth in the spirit of vigilance and further strengthening of the spiritual and educational work. 


\begin{tabular}{l|lrl|l|ll} 
& ISRA (India) & $=\mathbf{1 . 3 4 4}$ & SIS (USA) & $=\mathbf{0 . 9 1 2}$ & ICV (Poland) & $=\mathbf{6 . 6 3 0}$ \\
Impact Factor: & ISI (Dubai, UAE) $=\mathbf{0 . 8 2 9}$ & PUHIL (Russia) $=\mathbf{0 . 2 3 4}$ & PIF (India) & $=\mathbf{1 . 9 4 0}$ \\
& GIF (Australia) & $\mathbf{0 . 5 6 4}$ & ESJI (KZ) & $=\mathbf{1 . 0 4 2}$ & IBI (India) & $\mathbf{= 4 . 2 6 0}$ \\
& JIF & $\mathbf{1 . 5 0 0}$ & SJIF (Morocco) & $=\mathbf{2 . 0 3 1}$ & & \\
\hline
\end{tabular}

\section{References:}

1. (2014) Constitution of the republic of Uzbekistan.-T.: "Uzbekistan" publishing house, 2014. p.6.

2. (2017) Ideya nacional'noj nezavisimosti // Available:

http://faylasuf.uz/index.php/nazariy/zamonaviymuammolar/milliy-goya/349-ideyanatsionalnoj-nezavisimosti (Accessed: 10.01.2017).

3. Imomnazarov M (1996) Milliy ma'naviyatimizning takomil bosqichlari.

Toshkent: Sharq.

4. Jalolov AM (1998) Ma'naviyat tarkibida falsafiy tafakkurning urni. Mulokot. -1998. -№ 1. - p. 23-30.

5. Karimov IA (2008) Yuksak ma'naviyat yengilmas kuch. - Toshkent: Ma'naviyat.

6. Karimov IA (2011) O`zbekiston mustaqillikka erishish ostonasida. -Toshkent: O`zbekiston.

7. Karimov S, Shamsuddinov R (1997) Vatan tarixi. -Toshkent: O`qituvchi.

8. (2016) Kriticheskij analiz, zhestkaya disciplina i personal'naya otvetstvennost' dolzhny stat' povsednevnoj normoj $\mathrm{v}$ deyatel'nosti kazhdogo rukovoditelya. Doklad Prezidenta Respubliki Uzbekistan Shavkata Mirziyoeva na rasshirennom zasedanii Kabineta Ministrov, posvyashchennom itogam social'noehkonomicheskogo razvitiya strany v 2016 godu i vazhnejshim prioritetnym napravleniyam ehkonomicheskoj programmy na $2017 \operatorname{god} / /$ Available: http://press-service.uz/ru/news/5451/ (Accessed: 10.01.2017).

9. Kuchkorov V (2013) Milliy uzlikni anglash va barkaror tarakkiyot. - T.: Akademiya, 2013, p.44-45.

10. Meliev H (2017) Uspeshnyj mezhkonfessional'nyj dialog - zalog religioznoj svobody v Uzbekistane. Available: http://www.minjust.uz/ru/press/ourpublications/ 2013/06/3842/ (Accessed: 10.01.2017).

11. Turgunov A (2017) Mesto ideologicheskih faktorov v razvitii grazhdanskogo obshchestva. Available:

http://credonew.ru/content/view/1176/67/ (Accessed: 10.01.2017). 